\title{
All-endoscopic management of benign bone lesions; a case series of 26 cases with minimum of 2 years follow-up
}

\author{
Hazem A. Farouk*, Mostafa Saladin, Wessam Abu Senna, and Walid Ebeid \\ Orthopedics \& Trauma Surgery Department, Faculty of Medicine, Cairo University, Cairo, Egypt
}

Received 21 April 2018, Accepted 10 August 2018, Published online 22 November 2018

\begin{abstract}
Purpose: Assessment of the functional and oncologic outcomes regarding endoscopic curettage of different benign bone tumor types within variable anatomic locations.

Patients and methods: During the period between February 2012 and December 2016, 26 patients with symptomatic intra-osseous benign bony lesions were included. The age ranged from 3 up to 49 years (mean 20), of 14 females and 12 males. The follow-up duration ranged from 26 up to 58 months (mean 41). Functional scoring was done according to the Revised Musculoskeletal Tumour Society Rating Scale. Anatomic locations of the lesions included: 6 cases in the proximal tibia, 6 cases in the distal femur, 4 cases in the calcaneus, 3 cases in the proximal humerus, 3 cases in the distal tibia, 2 cases in the talus, 1 case in the proximal femur, and 1 case in the distal fibula. The procedure used $4 \mathrm{~mm} 30^{\circ}$ scope for endoscopy, and high speed burrs $3.5-5 \mathrm{~mm}$ for extended curettage. Autogenous bone grafting was done in 5 cases, and adjuvant material (polymethylmethacrylate) was needed in 7 cases.

Results: After exclusion of one case that was lost in the follow-up, the remaining 25 cases showed full functional recovery at a period of 8-12 weeks, and improved mean functional scores from 20.2 to $28.6 / 30$ postoperatively, with $p$ value $<0.001$ which was considered as a statistically significant result. The oncologic outcome showed 24 cases with adequate healing, while 1 case developed recurrence (aneurysmal bone cyst in the proximal tibia) for which, an open revision surgery was performed. Intra-operative fracture occurred in another case with aneurysmal bone cyst of the proximal femur, which was fixed by flexible nails with complete healing.

Conclusion: Endoscopic curettage of different types of intra-osseous benign bony lesions proved to be an effective treatment modality with promising oncologic outcome, improved functional scores, and fast functional recovery.
\end{abstract}

Key words: Bone tumors, Giant cell tumors, Bone cysts, Endoscopic curettage.

\section{Introduction}

Benign bone lesions are of various types and may occur in different parts of the skeleton. Some types of benign bone tumors are aggressive in behavior leading to break of their cortical shell and sometimes soft tissue involvement. Thus, management of benign bone tumors differs according to the type and their behavior ranging from non-operative management with observation of the lesion, intra-lesional injection or curettage with or without grafting, or adjuvant therapy. Finally, marginal or even wide resection may be needed in aggressive lesions with soft tissue involvement. All forms of treatment aim at pain relief, promotion of healing, and prevention of adverse complications like recurrence and pathological fractures [1].

\footnotetext{
*Corresponding author: hfarouk@kasralainy.edu.eg
}

Open surgical procedures often cause intraoperative bleeding, prolonged hospitalization, and wound-related complications. So, percutaneous measures have been developed to facilitate the surgery and decrease such undesirable complications. However, these sacrifice the potential advantages of direct exposure needed for adequate surgical management particularly in aggressive lesions with higher risk of recurrence [2-4]. That is why, the use of endoscopy in management of these lesions would be of tremendous help to avoid the problems of open surgery yet, having the advantage of a more accurate assessment of the extent of the lesion with the adequacy of the curettage [5].

The great success of arthroscopic-assisted techniques in management of benign synovial and juxta-articular bone lesions [6-9] aroused the motivation for the development of the new era of endoscopic-aided treatment of benign bone tumors. Thus, we hypothesize that 
management of benign bone lesions using all endoscopic technique could avoid morbidities associated with open procedures as stated above, yet successfully and efficiently managing the lesions with comparable success rates to open classic techniques. Therefore, the purpose of this study is to evaluate functional and radiological outcomes after all endoscopic treatment of different benign bone lesions.

\section{Patients and methods}

During the period between February 2012 and December 2016, 26 patients with benign bone lesions were enrolled in a prospective case series study to assess the efficacy of endoscopic curettage procedure. The age ranged from 3 up to 49 years with a mean of 18.4 years (SD 11.45), for 14 females and 12 males, with a minimum follow-up duration of 26 months and maximum of 58 months with a mean of 41.1 months (SD 10.2). All Patients with symptomatic benign bone lesions were included in our study. Exclusion criteria included lesions with extra osseous soft tissue extent, and lesions with previous open surgical interventions.

Preoperatively, all patients were clinically and radiologically evaluated and data were recorded. Functional scoring was done according to the Revised Musculoskeletal Tumour Society Rating Scale [10]. This score assesses the pain, restriction to function, and level of satisfaction of the patient either in the upper or lower limbs. Specific assessment to either limbs is incorporated according to the primary role of the limb (for example, gait, weight bearing and need for external support are items included in assessment of the lower limb valuation while the hand position, ability to lift, and manual dexterity are included in upper limb assessment). Radiological evaluation was done using plain radiographs, while MRI evaluation was needed in cases with doubtful diagnosis. CT-guided core biopsy was required in 15 cases, in which radiography was not conclusive for initial diagnosis.

All operative data were reported including the medications used, type of anesthesia, patient positioning, and the use of tourniquet. The surgical steps included portals choice, the curettage procedure, and tissue material obtained for gross examination and histopathological confirmation. The use of adjuvant materials, grafts, or implants. The need for blood transfusion or drains, the operative time, and finally the overall duration of the hospital stay (Table 1).

The anatomic locations of the lesions included: 6 cases in the proximal tibia, 6 cases in the distal femur, 4 cases in the calcaneus, 3 cases in the proximal humerus, 3 cases in the distal tibia, 2 cases in the talus, 1 case in the proximal femur, and 1 case in the distal fibula.

General anesthesia was performed in 11 cases while regional anesthesia (spinal) was performed in 15 cases. Hypotensive measures were taken to minimize bleeding particularly in cases where tourniquet application was not feasible, also for better field visualization. The duration of hospital stay was 3 days in 3 cases, 2 days in 7 cases, and 1 day in 16 cases. The patient position varied according to the anatomic location of the lesion, whether supine semisitting position in proximal humeral lesions. Supine position with hip elevation in lesions of the proximal femur, supine position with elevation and bending of the knee in lesions of the distal femur and proximal tibia, supine position with leg and ankle elevation in lesions of the distal tibia and fibula, and lateral position with heal elevation in lesions of the calcaneus and talus.

Exsanguination and tourniquet application were crucial in our study in order to decrease the blood loss, and for better clear operative field visualization. Tourniquet was applied in 22 cases and not feasible in 3 cases in the proximal humerus and a case in the proximal femur.

Portals choice were dependent on the site of the lesion within the bone, the safe zones to avoid nearby neurovascular structures, and the feasibility of proper triangulation to ensure smooth easy movement of instruments within the lesion for adequate visualization and proper curettage of tumor tissues.

Access into the lesions was done using blunt trocars ( $4 \mathrm{~mm}$ in diameter) which were introduced either by T-handle or by pre-drilling the cortex with a $3.5 \mathrm{~mm}$ drill bit. None of our lesions were small enough to necessities the use of smaller sized trochars. This was followed by gross curettage using ordinary curved or straight curettes, together with punches and graspers of different sizes. Endoscopic visualization using $4 \mathrm{~mm} 30^{\circ}$ scope was applied. Motorized high speed burrs of different sizes ranging from 3.5 to $5 \mathrm{~mm}$ were used for extended curettage (Figure 1).

Autogenous bone grafting was done in 5 cases. While adjuvant material (polymethylmethacrylate) was needed in 7 cases by injection through any of the portals.

The patients were followed up at 2 weeks for stitches removal, then at 6 and 12 weeks and every 3 months afterwards till the end of first year, then half yearly afterwards. Functional evaluation using the same rating scale was done; also the time of return to normal functional activities was reported. Also radiographic evaluation of healing or progression of lesions was done.

\section{Results}

The final functional scoring results according to Revised Musculoskeletal Society Rating Scale were score 30 in 13 cases, score 29 in 3 cases, score 28 in 5 cases, score 27 in 2 cases, score 26 in 1 case, score 20 in 1 case, and 1 case was lost follow-up with the mean score (28.6).

Statistical analysis of the functional scoring results after excluding the missed follow-up case using paired T-Test described in (Figure 2) as the following.

The pre-operative mean functional score was (20.2) with 1.89 standard deviation. The post-operative mean functional score was (28.6) with 2.25 standard deviation with $p$ value $<0.001$ which was considered as a statistically significant result. 


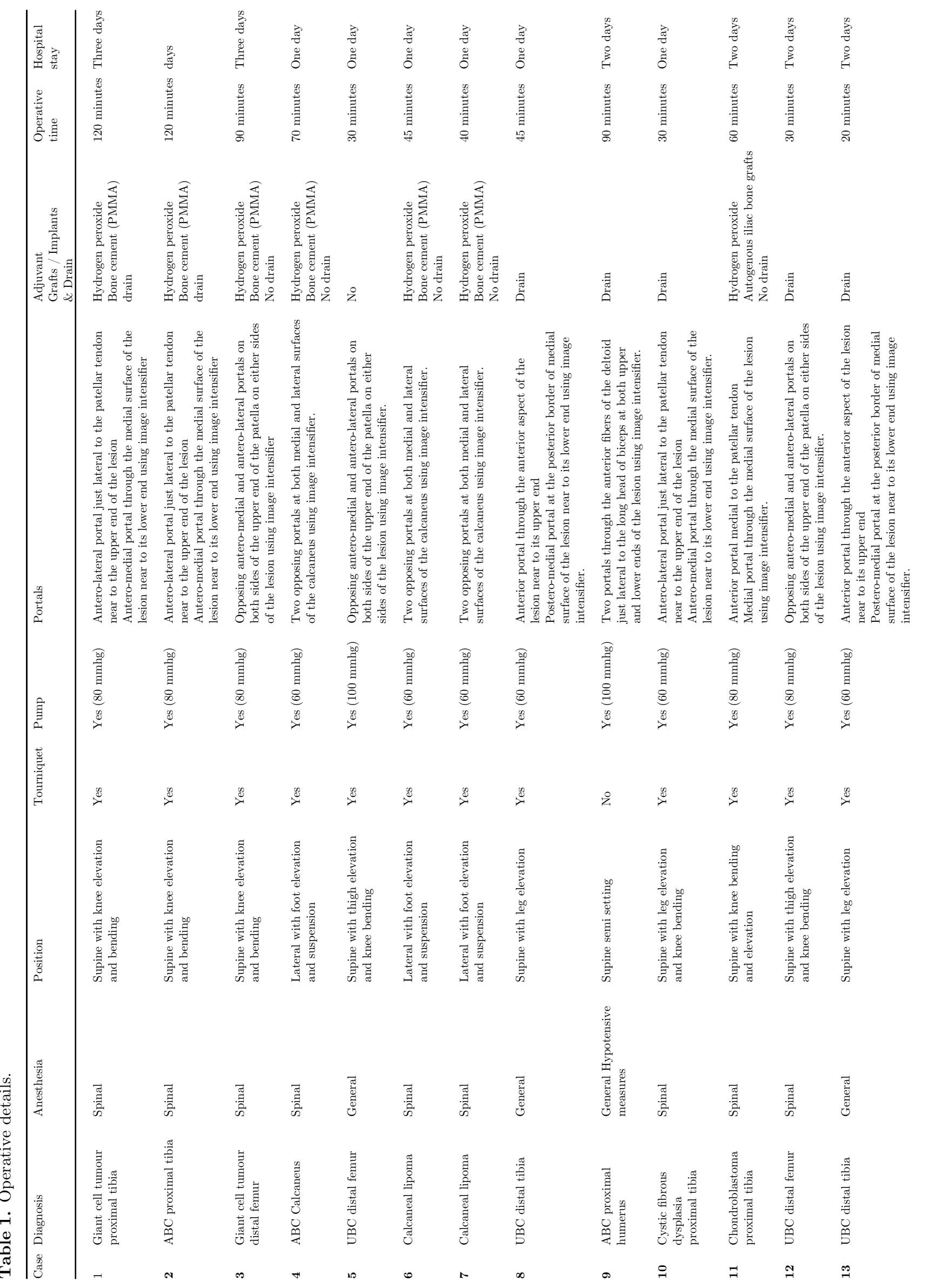




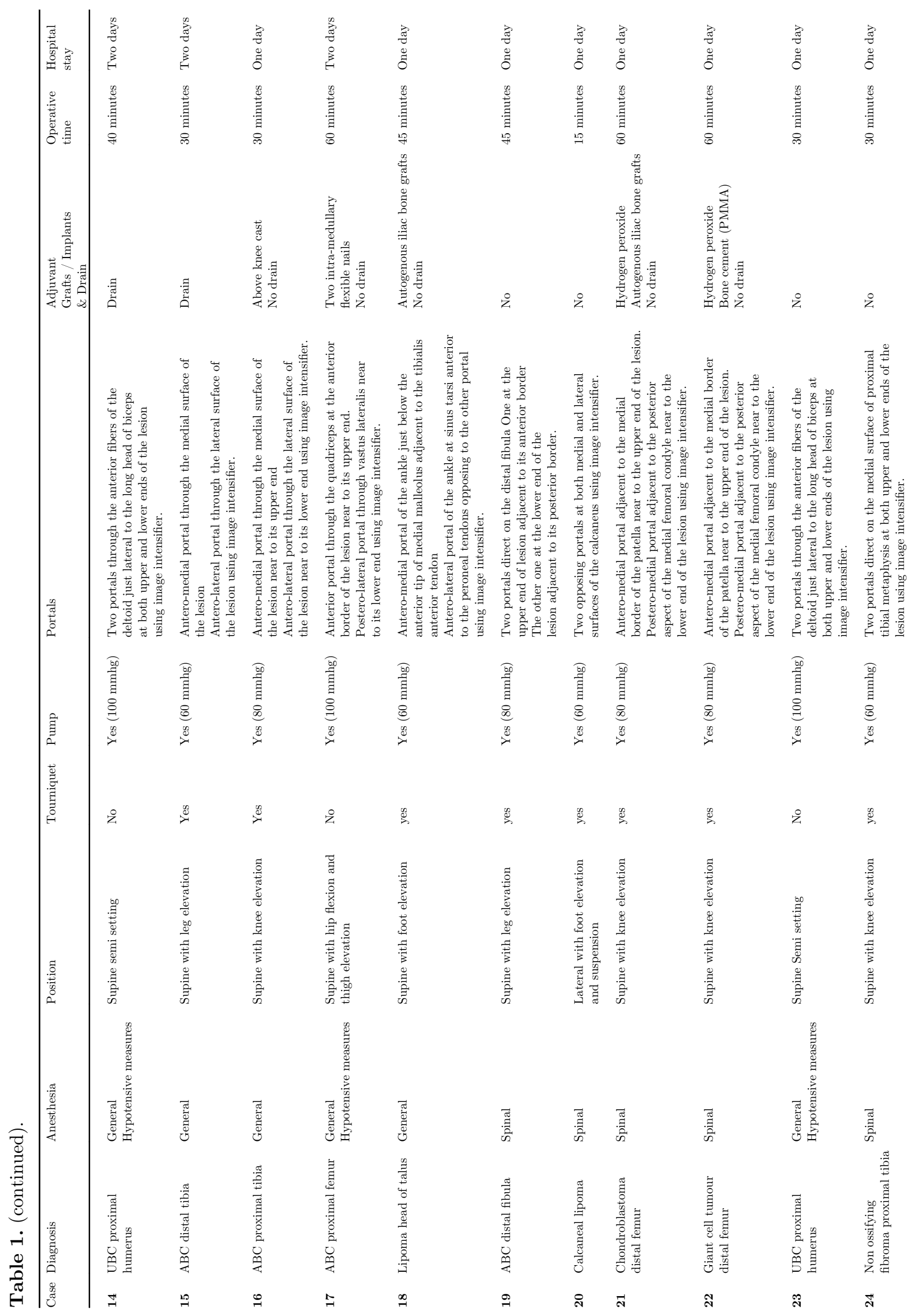


One case with calcaneal lipoma had been lost in the follow-up, and the remaining 25 cases were followed up for the time they return to full function which ranged from 8 up to 12 weeks.

The radiological outcome of the lesions showed 24 cases with adequate healing, while 1 case developed recurrence (ABC in the proximal tibia), and 1 case (Calcaneal Lipoma) had lost follow-up (Figures 3-5).

The final post-operative histopathologic diagnosis was as following: 8 cases of aneurysmal bone cyst, 6 cases of unicameral bone cyst, 4 cases of intra-osseous lipoma, 3 cases of giant cell tumour, 3 cases of chondroblastoma, a case of fibrous dysplasia, and finally a case of non-ossifying fibroma (Table 2).

Complications in our study included one case of local recurrence that was associated with lower limb varus malalignment. Another complication encountered was intra-operative fracture during the endoscopic procedure in one case. No reported scope related complications including: Portal track infection, fluid leakage with compartment syndrome, and thromboembolic complications. No reported neuro-vascular injury.

Local recurrence developed in 11 years old female patient with an expansile aneurysmal bone cyst in the proximal tibia (case 16). Endoscopic curettage without grafting was carried out. Follow-up serial radiographs showed proper healing and cortical thickening, so assisted weight bearing started at 8 weeks, and full weight bearing at 10 weeks post-operatively. At a period of 4 months she experienced gradual progressive pain which was aggravated by weight bearing, and a concomitant night pain. Also she developed an associated lower limb varus malalignment. The follow-up plain radiograph showed lysis in previously healed areas with cortical expansion (signs of recurrence) as shown previously (Figure 5). Further MRI study and CTguided core biopsy had confirmed the diagnosis of recurrence. Finally open extended curettage with iliac crest grafting and internal fixation using plate and screws was done (Figure 6). The revision surgery operative time was 120 minutes, blood loss was around $1500 \mathrm{~mL}$ where 2 units of blood were given, and the overall duration of hospital stay was 4 days.

Another case encountered an intra-operative fracture in 10 years old female patient with an aneurysmal bone cyst in the proximal femur (case 17). Endoscopic curettage was carried out without grafting, together with intraoperative fixation of the fracture by intramedullary flexible nails. Then she was splinted in hip spica cast for 8 weeks till the start of healing and union. After which full weight bearing was allowed at time of nails removal (12 weeks). Full bony union and complete healing of the lesion were achieved.

\section{Discussion}

This pilot study serves to throw more light on the results of using endoscopy in different benign bone tumors. The question was could we do safe endoscopic treatment 

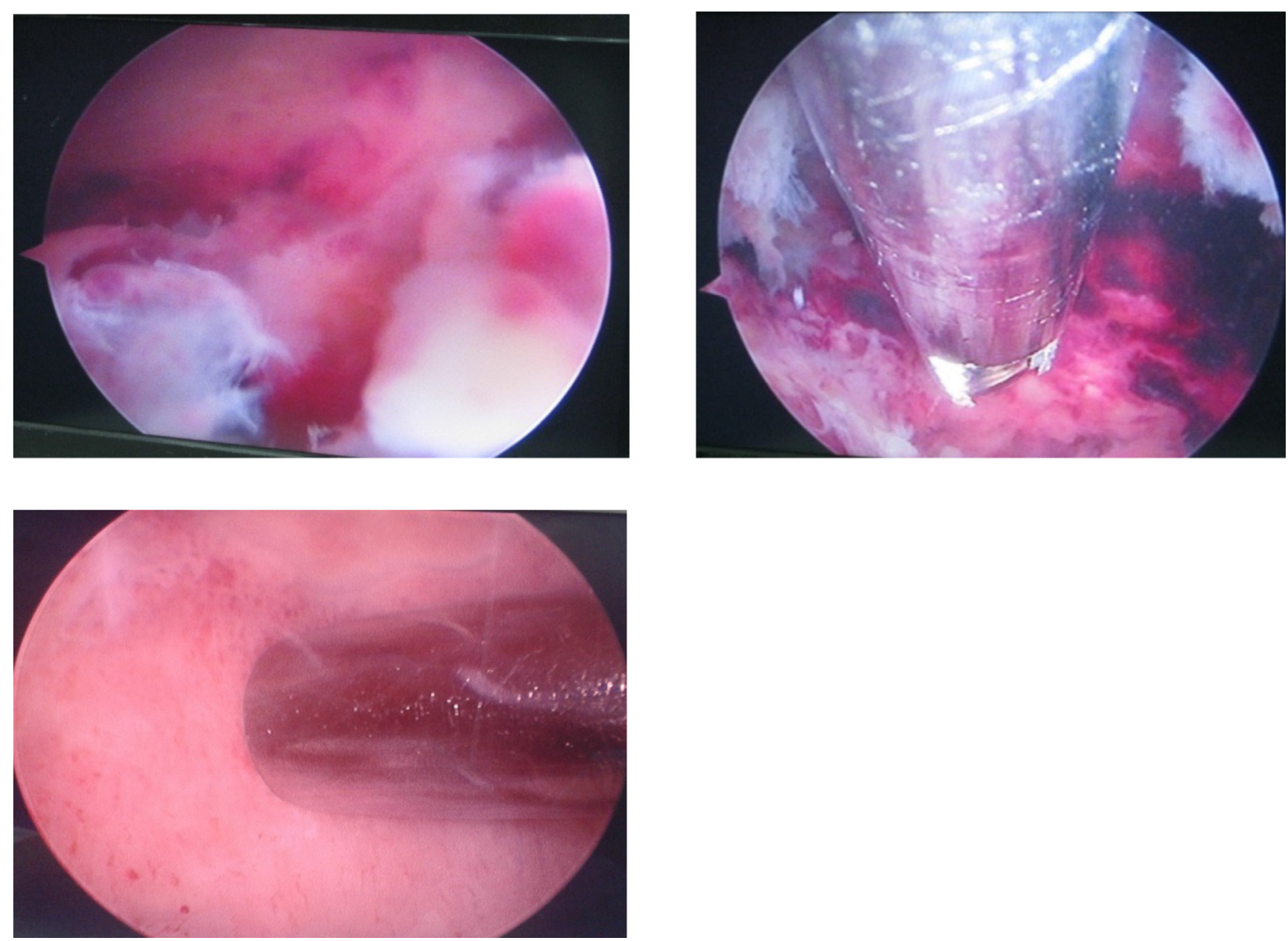

Figure 1. Serial pictures of endoscopic curettage procedure of an ABC (case 7) showing: first pic (top left) the lesion from inside after accessing it through its bony cortex with a trocar. Another portal was created to introduce a 3.5 blade of a motorized shaver followed by a blunt curette (top right). The curettage procedure ends when a healthy bony walls of the lesion (bottom) is clearly visualized from all angles.

\section{Mean functional scores}

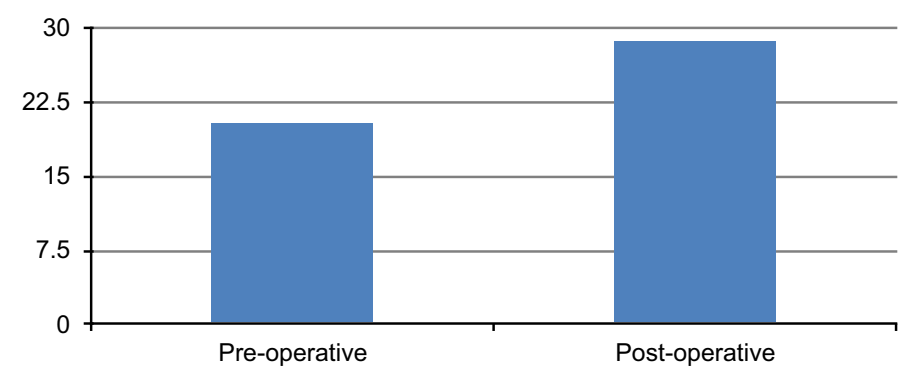

Figure 2. A column chart demonstrating the statistical analysis of the functional scoring results.

for different benign bone lesion types in variable anatomical locations? Adequacy was assessed through evaluating the oncological and functional outcome. Safety of the procedure was assessed by evaluating the associated complications. Most of the reported clinical trials in the literature showed successful oncological results (Table 3). The only exception was Choi et al. [5] who reported 4 cases of recurrences (simple bone cyst, fibrous dysplasia, aneurysmal bone cyst, and osteoblastoma) out of 32 cases.
Endoscopic surgical treatment maintains the structural integrity and the periosteal sleeve of the affected bones, with minimal cortical breakdown by small sized portals, so faster bone healing could be achieved. It has a minimal risk for local soft tissue injury and hence faster healing and better functional recovery. None of the related clinical trials in the literature up to our knowledge used a scoring system for functional evaluation of their cases and did not measure the time needed for recovery. Moreover, in the 


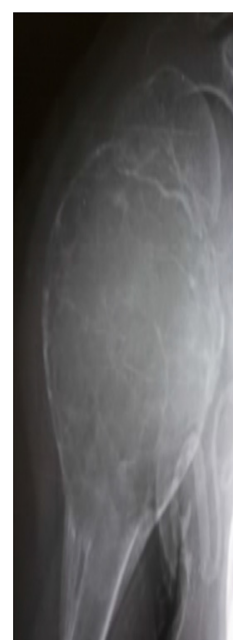

(A)

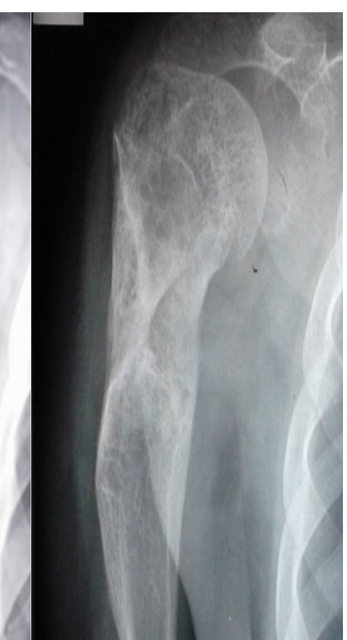

(C)

Figure 3. Serial plain radiographs (A) 11 years old patient with $\mathrm{ABC}$ lesion in the proximal humerus (case 9), (B) 4 weeks followup after endoscopic curettage without grafting showed new bone formation, and $(\mathrm{C})$ complete healing and remodeling after 24 months.

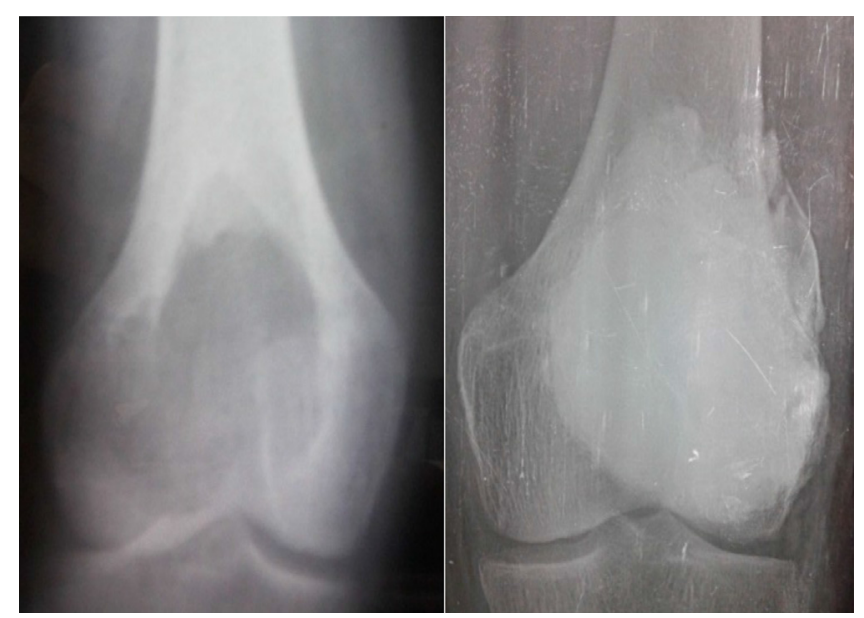

Figure 4. Serial plain radiographs (A) 18 years old patient with GCT in the distal femur (case 3), (B) 30 months last follow-up after endoscopic curettage and percutaneous bone cement application with no radiologic evidence of recurrence.

current study apart from the patient lost to follow up and the patient who developed local recurrence, all patients reached normal full functional activities at a period of 8-12 weeks post-operatively.

To our knowledge this study is considered as the second largest clinical trial after Choi et al. [5] in endoscopic management of benign bone tumors; regarding the number of cases included, and the variability of the anatomical locations and the pathological types of the treated lesions. Also the current study would be considered as the first clinical trial in endoscopic management of giant cell tumor of the bone (cases 1, 3, 22).

Complications in our study included 2 cases only; a case of local recurrence with lower limb varus

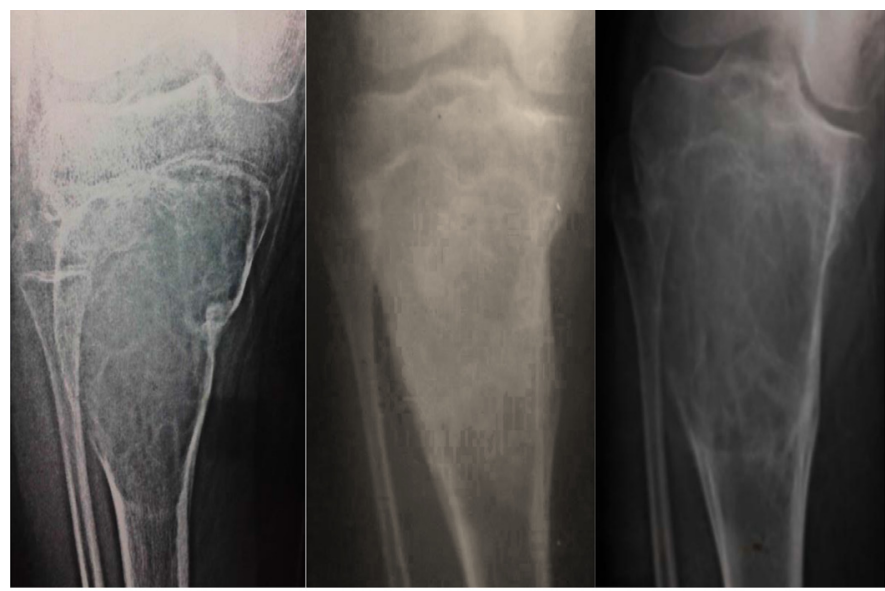

(A)

(B)

(C)

Figure 5. Serial radiographs of (A) 11 years old patient with ABC in the proximal tibia (case 16), (B) 3 months follow-up showed proper healing and cortical thickening, and (C) 5 months follow-up showed lysis in previously healed areas and bone expansion (signs of recurrence).

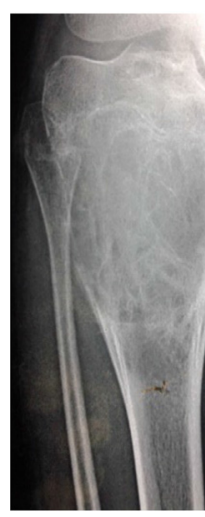

(A)

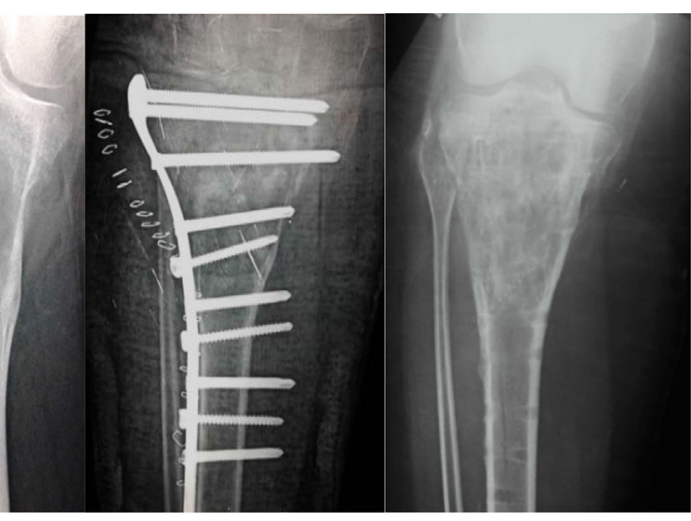

(B)
(C)
Figure 6. (A) Plain radiograph showed varus mal-alignment of recurrent $\mathrm{ABC}$ in the proximal tibia (case 16), (B) post-operative radiograph after revision surgery, and (c) last follow-up radiograph 32 months post-operative showed complete healing.

malalignment, and a case with intra-operative fracture. This is compared to Choi et al. [5] study which is the only study to report complications.

Comparison of the study results to other reported common clinical trials in the literature is described in (Table 3).

Our experience at the end of the study would suggest that variable pathologic types of contained intraosseous benign bone lesions within variable anatomical sites could be managed safely and effectively by endoscopic techniques. However technical difficulties varied from one lesion to another according to different variables. First, less visual field clarity was found with lesions of the proximal humerus (cases 9, 14, 23), and the proximal 
Table 2. A comparison of different clinical trials to the current study.

\begin{tabular}{|c|c|c|c|c|c|c|}
\hline Study & $\begin{array}{l}\text { Number } \\
\text { of cases }\end{array}$ & $\begin{array}{l}\text { Anatomical } \\
\text { sites }\end{array}$ & Pathological types & Functional result & $\begin{array}{l}\text { Oncological } \\
\text { result }\end{array}$ & Complications \\
\hline $\begin{array}{l}\text { Stricker } \\
1995[11]\end{array}$ & 3 & Femoral head & Chondroblastoma & Good & Healed & $\ldots \ldots \ldots$ \\
\hline $\begin{array}{l}\text { Bonnel et al. } \\
1999 \text { [12] }\end{array}$ & 1 & Calcaneus & $\mathrm{UBC}$ & Good & Healed & \\
\hline $\begin{array}{l}\text { Otsuka et al. } \\
2001 \text { [13] }\end{array}$ & 4 & $\begin{array}{l}\text { Patella } \\
\text { Proximal humerus } \\
\text { Proximal tibia } \\
\text { Calcaneus }\end{array}$ & $\begin{array}{l}\text { Atypical ABC no } \\
\text { aneurysmal } \\
\text { dilatation }\end{array}$ & Good & Healed & ......... \\
\hline $\begin{array}{l}\text { Otsuka et al. } \\
2002[14]\end{array}$ & 1 & Calcaneus & Chondroblastoma & Good & Healed & $\ldots \ldots \ldots$ \\
\hline $\begin{array}{l}\text { Dietz et al. } \\
2007 \text { [15] }\end{array}$ & 2 & Hand & Enchondroma & Good & Healed & ......... \\
\hline $\begin{array}{l}\text { Yildirim et al. } \\
2010 \text { [16] }\end{array}$ & 1 & Calcaneus & UBC & Good & Healed & $\ldots \ldots \ldots$ \\
\hline $\begin{array}{l}\text { Innami et al. } \\
2011[17]\end{array}$ & 13 & Calcaneus & $\mathrm{UBC}$ & Good & Healed & ......... \\
\hline $\begin{array}{l}\text { Yildirim et al. } \\
2011[18]\end{array}$ & 13 & Calcaneus & $\mathrm{UBC}$ & Good & Healed & $\ldots \ldots \ldots$ \\
\hline $\begin{array}{l}\text { Choi et al. } \\
2014[5]\end{array}$ & 32 & Not included & $\begin{array}{l}9 \text { UBC } \\
6 \text { Fibrous dysplasia } \\
5 \text { Enchondroma } \\
4 \text { NOF } \\
3 \text { Bone infarcts } \\
1 \text { ABC } \\
1 \text { Chondroblastoma } \\
1 \text { Osteoblastoma } \\
1 \text { Lipoma } \\
1 \text { Brodie abscess }\end{array}$ & Not included & $\begin{array}{l}21 \text { Excellent } \\
6 \text { Good } \\
1 \text { Poor } \\
4 \text { Recurrence }\end{array}$ & $\begin{array}{l}4 \text { Recurrence } \\
1 \text { Fracture } \\
1 \text { Infection }\end{array}$ \\
\hline Current study & 26 & $\begin{array}{l}6 \text { Proximal tibia } \\
6 \text { Distal femur } \\
4 \text { Calcaneus } \\
3 \text { Proximal humerus } \\
3 \text { Distal tibia } \\
1 \text { Proximal femur } \\
1 \text { Fibula } \\
2 \text { Talus }\end{array}$ & $\begin{array}{l}8 \text { ABC } \\
6 \text { UBC } \\
4 \text { Lipoma } \\
3 \text { GCT } \\
3 \text { Chondroblastoma } \\
1 \text { Fibrous dysplasia } \\
1 \text { NOF }\end{array}$ & $\begin{array}{l}\text { Except cases }(7,16) \\
\text { All cases reached } \\
\text { full recovery } \\
\text { within } 8 \text { to } 12 \text { weeks }\end{array}$ & $\begin{array}{l}24 \text { Healed } \\
1 \text { Recurrence } \\
1 \text { Lost follow-up }\end{array}$ & $\begin{array}{l}1 \text { Recurrence and } \\
\text { Varus lower } \\
\text { limb deformity } \\
1 \text { Fracture } \\
1 \text { Lost follow-up }\end{array}$ \\
\hline
\end{tabular}

$\mathrm{UBC}=$ unicameral bone cyst, $\mathrm{ABC}=$ aneurysmal bone cyst, $\mathrm{NOF}=$ non-ossifying fibroma, $\mathrm{GCT}=$ giant cell tumour, $\mathrm{BFH}=$ benign fibrous histocytosis.

femur (case 17). This was related to lack of tourniquet application, so we recommend hypotensive anesthesia, proper patient positioning, and using a pump system. Second, considerable difficulty in portals planning for the proximal femur lesion (case 17) was noted due to narrow safe zone, which made the process of triangulation more difficult. Thus, excessive manipulation (torsional stresses) was necessary during surgery, which leaded to an intraoperative fracture. Third, endoscopic management would be considered as the option of choice in lesions of the distal tibia and the foot as they have poor soft tissue envelope with more risk of open wound-related complications. Thus, it would be associated with lower morbidity and better outcome. Fourth, benign bone ${ }_{\text {Q2 }}$ lesions with solid components (such as giant cell tumor and chondroblastoma), and cystic lesions with abundant tissue and high vascularity (aneurysmal bone cyst) were more technically demanding, regarding a longer operative time needed for percutaneous gross tissue removal. Lastly, no major variation was found regarding the size of different bone lesions. However, massive lesion would be expected to take longer operative time. Also small-sized lesions would need an additional equipment set (scopes 2.5 or even $1.9 \mathrm{~mm}$ ) to deal with properly.

The weaknesses of the current study include lack of comparison to other conventional operative techniques due to the attenuated sample size. Moreover, we could not compare the results of endoscopic treatment of different types of benign bone tumors as this would need largersized patient groups for each type. Lastly, we could claim that the follow-up period was not long.

Our future recommendation is to use larger sample size and a longer follow-up period. Randomized control clinical trials are needed to compare the results of endoscopic surgery to that of other conventional types of treatment modalities. Also more trials will be needed to compare the 
Table 3. Summary of the study results.

\begin{tabular}{|c|c|c|c|c|c|c|c|c|}
\hline Case & $\begin{array}{l}\text { Age, } \\
\text { Sex }\end{array}$ & $\begin{array}{l}\text { Core-biopsy } \\
\text { result }\end{array}$ & Definitive diagnosis & Procedure & $\begin{array}{l}\text { Follow-up } \\
\text { period }\end{array}$ & $\begin{array}{l}\text { Functional } \\
\text { scoring } \\
\text { Pre } \backslash \text { Post } \\
\end{array}$ & $\begin{array}{l}\text { Radiologic } \\
\text { results }\end{array}$ & Complications \\
\hline 1 & $\begin{array}{l}18 \\
\mathrm{~F}\end{array}$ & $\mathrm{ABC}$ & $\begin{array}{l}\text { GCT of proximal } \\
\text { tibia }\end{array}$ & $\begin{array}{l}\text { Endo curettage } \\
\text { and cement }\end{array}$ & 58 months & $\begin{array}{l}20 \\
28\end{array}$ & Healed & ….......... \\
\hline 2 & $\begin{array}{l}36 \\
F\end{array}$ & $\mathrm{ABC}$ & $\begin{array}{l}\text { ABC of proximal } \\
\text { tibia }\end{array}$ & $\begin{array}{l}\text { Endo curettage } \\
\text { and cement }\end{array}$ & 58 months & $\begin{array}{l}18 \\
27\end{array}$ & Healed & ............. \\
\hline 3 & $\begin{array}{l}18 \\
F\end{array}$ & GCT & $\begin{array}{l}\text { GCT of distal } \\
\text { femur }\end{array}$ & $\begin{array}{l}\text { Endo curettage } \\
\text { and cement }\end{array}$ & 57 months & $\begin{array}{l}20 \\
28\end{array}$ & Healed & $\ldots \ldots \ldots \ldots$ \\
\hline 4 & $\begin{array}{l}21 \\
\mathrm{M}\end{array}$ & $\mathrm{ABC}$ & ABC calcaneus & $\begin{array}{l}\text { Endo curettage } \\
\text { and cement }\end{array}$ & 54months & $\begin{array}{l}18 \\
28\end{array}$ & Healed & $\ldots \ldots \ldots \ldots \ldots$ \\
\hline 5 & $\begin{array}{l}6 \\
\mathrm{M}\end{array}$ & Inconclusive & UBC distal femur & $\begin{array}{l}\text { Endo curettage } \\
\text { No graft }\end{array}$ & 54 months & $\begin{array}{l}22 \\
30\end{array}$ & Healed & $\ldots \ldots \ldots \ldots$ \\
\hline 6 & $\begin{array}{l}45 \\
\mathrm{M}\end{array}$ & - & Calcaneal lipoma & $\begin{array}{l}\text { Endo curettage } \\
\text { and cement }\end{array}$ & 52 months & $\begin{array}{l}24 \\
27\end{array}$ & Healed & $\longrightarrow$ \\
\hline 7 & $\begin{array}{l}37 \\
\mathrm{~F}\end{array}$ & - & Calcaneal lipoma & $\begin{array}{l}\text { Endo curettage } \\
\text { and cement }\end{array}$ & 50 months & 22 & Lost & Lost follow-up \\
\hline 8 & $\begin{array}{l}3 \\
F\end{array}$ & Inconclusive & UBC distal tibia & $\begin{array}{l}\text { Endo curettage } \\
\text { No graft, slab }\end{array}$ & 49months & $\begin{array}{l}19 \\
30\end{array}$ & Healed & ............. \\
\hline 9 & $\begin{array}{l}11 \\
F\end{array}$ & $\mathrm{ABC}$ & $\begin{array}{l}\text { ABC proximal } \\
\text { humerus }\end{array}$ & $\begin{array}{l}\text { Endo curettage } \\
\text { No graft }\end{array}$ & 49 months & $\begin{array}{l}20 \\
28\end{array}$ & Healed & $\ldots \ldots \ldots \ldots$ \\
\hline 10 & $\begin{array}{l}16 \\
\mathrm{M}\end{array}$ & - & F.D proximal tibia & $\begin{array}{l}\text { Endo curettage } \\
\text { No graft }\end{array}$ & 45 months & $\begin{array}{l}22 \\
30\end{array}$ & Healed & …......... \\
\hline 11 & $\begin{array}{l}19 \\
\mathrm{M}\end{array}$ & Chondroblastoma & $\begin{array}{l}\text { Chondroblastoma } \\
\text { Proximal tibia }\end{array}$ & $\begin{array}{l}\text { Endo curettage } \\
\text { and grafting }\end{array}$ & 45 months & $\begin{array}{l}19 \\
30\end{array}$ & Healed & $\ldots \ldots \ldots \ldots$ \\
\hline 12 & $\begin{array}{l}23 \\
F\end{array}$ & - & UBC distal femur & $\begin{array}{l}\text { Endo curettage } \\
\text { No graft }\end{array}$ & 39 months & $\begin{array}{l}22 \\
30\end{array}$ & Healed & ….......... \\
\hline 13 & $\begin{array}{l}14 \\
\mathrm{~F}\end{array}$ & $\longrightarrow$ & UBC distal tibia & $\begin{array}{l}\text { Endo curettage } \\
\text { No graft }\end{array}$ & 36 months & $\begin{array}{l}20 \\
28\end{array}$ & Healed & \\
\hline 14 & $\begin{array}{l}15 \\
\mathrm{M}\end{array}$ & - & $\begin{array}{l}\text { UBC proximal } \\
\text { humerus }\end{array}$ & $\begin{array}{l}\text { Endo curettage } \\
\text { No graft }\end{array}$ & 36 months & $\begin{array}{l}22 \\
30\end{array}$ & Healed & ………..... \\
\hline 15 & $\begin{array}{l}9 \\
\mathrm{~F}\end{array}$ & $\longrightarrow$ & $\mathrm{ABC}$ distal tibia & $\begin{array}{l}\text { Endo curettage } \\
\text { No graft }\end{array}$ & 35 months & $\begin{array}{l}19 \\
30\end{array}$ & Healed & .............. \\
\hline 16 & $\begin{array}{l}11 \\
\mathrm{~F}\end{array}$ & UBC & ABC proximal tibia & $\begin{array}{l}\text { Endo curettage } \\
\text { No graft, slab }\end{array}$ & 35 months & $\begin{array}{l}16 \\
20\end{array}$ & Recurrent & $\begin{array}{l}\text { Recurrence } \\
\text { Varus deformity }\end{array}$ \\
\hline 17 & $\begin{array}{l}10 \\
\mathrm{~F}\end{array}$ & $\mathrm{ABC}$ & $\mathrm{ABC}$ proximal femur & $\begin{array}{l}\text { Endo curettage } \\
\text { No graft, I.M } \\
\text { nails spica }\end{array}$ & 35 months & $\begin{array}{l}18 \\
29\end{array}$ & Healed & Fracture \\
\hline 18 & $\begin{array}{l}11 \\
M\end{array}$ & Lipoma & Lipoma head of talus & $\begin{array}{l}\text { Endo curettage } \\
\text { and graft, slab }\end{array}$ & 34 months & $\begin{array}{l}22 \\
30\end{array}$ & Healed & .............. \\
\hline 19 & $\begin{array}{l}43 \\
F\end{array}$ & $\mathrm{ABC}$ & $\mathrm{ABC}$ distal fibula & $\begin{array}{l}\text { Endo curettage } \\
\text { No graft }\end{array}$ & 34 months & $\begin{array}{l}20 \\
29\end{array}$ & Healed & $\ldots \ldots \ldots \ldots$ \\
\hline 20 & $\begin{array}{l}49 \\
\mathrm{M}\end{array}$ & - & Calcaneal lipoma & $\begin{array}{l}\text { Endo curettage } \\
\text { No graft }\end{array}$ & 33 months & $\begin{array}{l}22 \\
26\end{array}$ & Healed & $\ldots \ldots \ldots \ldots$ \\
\hline 21 & $\begin{array}{l}19 \\
M\end{array}$ & Chondroblastoma & $\begin{array}{l}\text { Chondroblastoma } \\
\text { distal femur }\end{array}$ & $\begin{array}{l}\text { Endo curettage } \\
\text { and graft }\end{array}$ & 32 months & $\begin{array}{l}20 \\
30\end{array}$ & Healed & …......... \\
\hline 22 & $\begin{array}{l}22 \\
F\end{array}$ & GCT & GCT distal femur & $\begin{array}{l}\text { Endo curettage } \\
\text { and cement }\end{array}$ & 32 months & 18 & Healed & ……….... \\
\hline 23 & $\begin{array}{l}12 \\
F\end{array}$ & 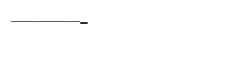 & $\begin{array}{l}\text { UBC proximal } \\
\text { humerus }\end{array}$ & $\begin{array}{l}\text { Endo curettage } \\
\text { No graft }\end{array}$ & 32 months & $\begin{array}{l}22 \\
30\end{array}$ & Healed & \\
\hline 24 & $\begin{array}{l}16 \\
\mathrm{M}\end{array}$ & NOF & NOF proximal tibia & $\begin{array}{l}\text { Endo curettage } \\
\text { No graft }\end{array}$ & 31 months & $\begin{array}{l}20 \\
30\end{array}$ & Healed & ……….... \\
\hline 25 & $\begin{array}{l}23 \\
M\end{array}$ & $\ldots \ldots \ldots \ldots \ldots \ldots$ & ABC body Talus & $\begin{array}{l}\text { Endo curettage } \\
\text { And graft }\end{array}$ & 28 months & $\begin{array}{l}22 \\
29\end{array}$ & Healed & $\ldots \ldots \ldots \ldots \ldots$ \\
\hline 26 & $\begin{array}{l}12 \\
\mathrm{M}\end{array}$ & .................. & $\begin{array}{l}\text { Chondroblastoma } \\
\text { distal femur }\end{array}$ & $\begin{array}{l}\text { Endo curettage } \\
\text { And graft }\end{array}$ & 26 months & $\begin{array}{l}22 \\
30\end{array}$ & Healed & ...…….......... \\
\hline
\end{tabular}

$\mathrm{M}=$ male, $\mathrm{F}=$ female, Endo=endoscopic, $\mathrm{I} \cdot \mathrm{M}=$ intramedullary, $\mathrm{F} . \mathrm{D}=$ fibrous dysplasia, $\mathrm{UBC}=$ unicameral bone cyst, $\mathrm{ABC}=$ aneurysmal bone cyst, $\mathrm{NOF}=$ non-ossifying fibroma, GCT $=$ giant cell tumour. 
effectiveness of endoscopic surgery within different groups of benign bone lesion types in variable anatomical locations.

\section{Conclusion}

Endoscopic-assisted surgical technique proves to be an effective method in management of symptomatic cases with contained intra-osseous benign bony lesions of different pathologic types in different anatomic locations. Also as being a percutaneous minimally invasive technique, it has the potential advantages of keeping the structural integrity and the periosteal continuity of the affected bone, with better healing potentials and faster recovery. Finally it provides proper direct exposure of the entire lesion with careful assessment of the adequacy of curettage, and thus, a lower risk of recurrence.

\section{Conflict of interest}

The authors declare that they have no conflicts of interest in relation to this article.

\section{References}

1. Steffner R (2014) Benign bone tumors. Cancer Treat Res 162, 31-63.

2. Mik G, Arkader A, Manteghi A, Dormans JP (2009) Results of a minimally invasive technique for treatment of unicameral bone cysts. Clin Orthop Relat Res 467(11), 2949-2954.

3. Hou HY, Wang CT, Chang SM, Lin WH, Yang RS (2011) Treatment of unicameral bone cyst: surgical technique. J Bone Joint Surg Am 93(Suppl 1), 92-9.

4. Glanzmann MC, Campos L (2007) Flexible intramedullary nailing for unicameral cysts in children's long bones: level of evidence: $\mathrm{lV}$, case series. J Child Orthop 1(2), 97-100.

5. Choi Y, Kwak JM, Chung SH, Jung GH, Kim JD (2014) Tumor treated by endoscopy. Clin Orthop Surg 6(1), $72-79$.

6. Ogilvie-Harris DJ, Saleh K (1994) Generalized synovial chondromatosis of the knee: a comparison of removal of the loose bodies alone with arthroscopic synovectomy. Arthroscopy 10(2), 166-170.

7. Lee JB, Kang C, Lee CH, Kim PS, Hwang DS (2012) Arthroscopic treatment of synovial chondromatosis of the hip. Am J Sports Med 40(6), 1412-1418.

8. Schmoyer S, Ciullo JV (2001) Arthroscopic resection of an osteochondroma of the knee. Arthroscopy 17(7), 765-767.

9. Chang BK, Ha YC, Lee YK, Hwang DS, Koo KH (2010) Arthroscopic excision of osteoid osteoma in the posteroinferior portion of the acetabulum. Knee Surg Sports Traumatol Arthrosc 18(12), 1685-1687.

10. Enneking WF, Dunham W, Gebhardt MC, Malawar M, Pritchard DJ (1993) A system for the functional evaluation of reconstructive procedures after surgical treatment of tumors of the musculoskeletal system. Clin Orthop Relat Res (286), 241-246.

11. Stricker SJ (1995) Extraarticular endoscopic excision of femoral headchondroblastoma. J Pediatr Orthop 15(5), Q4 $578-581$

12. Bonnel F, Canovas F, Faure P (1999) Treatment of a simple bone cyst of the calcaneus by endoscopic curettage with cancellous bone injection. Acta Orthop Belg 65(4), $528-531$

13. Otsuka T, Kobayashi M, Sekiya I, Yonezawa M, Kamiyama F, Matsushita Y, Matsui N (2001) A new treatment of aneurysmal bone cyst by endoscopic curettage without bone grafting. Arthroscopy 17(7), E28.

14. Otsuka T, Kobayashi M, Yonezawa M, Kamiyama F, Matsushita Y Matsui N (2002) Treatment of chondroblastoma of the calcaneus with a secondary aneurysmal bone cyst using endoscopic curettage without bone grafting. Arthroscopy 18(4), 430-435.

15. Dietz JF, Kachar SM, Nagle DJ (2007) Endoscopically assisted excision of digital enchondroma. Arthroscopy 23(6), 678 e1-4.

16. Yildirim C, Mahirogullari M, Kuskucu M, Akmaz I, Keklikci K (2010) Treatment of a unicameral bone cyst of calcaneus with endoscopic curettage and percutaneous filling with corticocancellous allograft. J Foot Ankle Surg 49(1), 93-97.

17. Innami K, Takao M, Miyamoto W, Abe S, Nishi H, Matsushita T (2011) Endoscopic surgery for young athletes with symptomatic unicameral bone cyst of the calcaneus. Am J Sports Med 39(3), 575-581.

18. Yildirim C, Akmaz I, S ahin O, Keklikci K (2011) Simple calcaneal bone cysts: a pilot study comparing open versus endoscopic curettage and grafting. J Bone Joint Surg Br 93(12), 1626-1631.

Cite this article as: Farouk HA, Saladin M, Senna WA, Ebeid W (2018) All-endoscopic management of benign bone lesions; a case series of 26 cases with minimum of 2 years follow-up. SICOT-J, 4, 50. 